\title{
Selective digestive decontamination is superior to oropharyngeal chlorhexidine in preventing pneumonia and reducing mortality in critically ill patients
}

\author{
A descontaminação digestiva seletiva é superior à clorexidina via \\ orofaringe na prevenção de pneumonia e na redução da mortalidade em \\ pacientes criticamente enfermos
}

\section{To the Editor:}

We welcome the review article entitled "Nosocomial pneumonia: importance of the oral environment" by Amaral et al., as they unequivocally acknowledge the two fundamentals of pneumonia prevention in patients requiring treatment in the $\mathrm{ICU} .{ }^{(1)}$ First, pathogens in the oropharynx cause lower airway infections, and second, eradication of oropharyngeal pathogens prevents lower airway infections. The authors advocate pharmacological interventions to prevent pneumonia, including "decontamination with the administration of systemic antibiotics" and "local decontamination with the topical use of oral antiseptic and toothbrushing". We were surprised by the ready dismissal of the issue of selective digestive decontamination (SDD), since the authors cited only one randomized controlled trial (RCT) using oropharyngeal decontamination with $2 \%$ gentamicin, polymyxin B and vancomycin, whereas the use of chlorhexidine was widely supported.

The issue of SDD has been addressed in 60 RCTs and 10 meta-analyses including only RCTs (Chart 1). In all meta-analyses in which pneumonia was the endpoint, SDD using parenteral, as well as enteral (oropharyngeal and intestinal), antimicrobials has consistently been shown to reduce the number of cases of pneumonia. The parenteral component effectively controls primary endogenous pneumonias caused by "normal" bacteria, whereas the enteral antimicrobials reduce secondary endogenous pneumonias due to "abnormal" bacteria, including Pseudomonas spp. and Acinetobacter spp. Although the authors are concerned about Actinomyces spp., this microorganism cannot be considered to be among the potential agents of pneumonia in mechanically ventilated ICU patients. Nevertheless, Actinomyces spp. are covered by the SDD antimicrobials. In 8 of the 10 meta-analyses, mortality was the outcome measure. There was a consistent survival benefit in all meta-analyses that assessed the full SDD protocol with parenteral and enteral antimicrobials, assuming that the sample size was sufficient. Opinion leaders have expressed concerns regarding resistance, and, despite the fact that those concerns are based on low level evidence, this has hindered the implementation of SDD. Resistance was not a clinically relevant problem in the 60 RCTs evaluating SDD. ${ }^{(2)}$ Two large Dutch RCTs in which the endpoint was resistance demonstrated that the carriage of and infection with multiresistant aerobic gramnegative bacilli were significantly lower after SDD than after the standard therapy. ${ }^{(3)}$

The use of selective oropharyngeal decontamination (SOD) alone, rather than the full SDD protocol, has recently been advocated. However, a recent meta-analysis demonstrated that SOD significantly reduces lower respiratory tract infections but does not reduce mortality. ${ }^{(4)}$

In their review, Amaral et al. focused most of their attention on the role that the oropharyngeal application of antiseptics, mainly chlorhexidine, plays in the prevention of ventilator-associated pneumonia (VAP). This preventive policy has been studied in several RCTs, with opposite results. To our knowledge, there have been only 5 metaanalyses of oral antiseptics, ${ }^{(5)}$ the majority of which concluded that oral antiseptics seem to be effective in reducing VAP. However, results from RCTs of oral antiseptics and from meta-analyses should be interpreted with caution. Two thirds of the population included in the meta-analyses were cardiac surgery patients who had received no more than two days of mechanical ventilation. ${ }^{(6)}$ Such patients should not be included in a meta-analysis in which the endpoint is VAP. In addition, the differences in terms of the definition of lower respiratory tract infections, as well as in the dosages and applications of antiseptics (e.g., chlorhexidine vs. povidone iodine; $0.12 \%$ vs. $2 \%$ chlorhexidine; use of solution, spray, gel or paste), might have influenced the results. In summary, it seems that oral antiseptics are 
Chart 1 - Efficacy of selective digestive decontamination in ten meta-analyses evaluating only randomized controlled trials.

\begin{tabular}{|c|c|c|c|c|c|}
\hline Authors & Year & $\begin{array}{c}\text { Lower airway } \\
\text { infection }\end{array}$ & $\begin{array}{c}\text { Bloodstream } \\
\text { infection }\end{array}$ & MODS & Mortality $^{\mathrm{a}}$ \\
\hline & & OR $(95 \% \mathrm{Cl})$ & OR $(95 \% \mathrm{Cl})$ & OR $(95 \% \mathrm{Cl})$ & OR $(95 \% \mathrm{Cl})$ \\
\hline Vandenbroucke-Grauls et al. ${ }^{(7)}$ & 1991 & $0.12(0.08-0.19)$ & & & $0.92(0.45-1.84)$ \\
\hline D’Amico et al. ${ }^{(8)}$ & 1998 & $0.35(0.29-0.41)$ & & & $0.80(0.69-0.93)$ \\
\hline Liberati et al. ${ }^{(9)}$ & 2004 & $0.35(0.29-0.41)$ & & & $0.78(0.68-0.89)$ \\
\hline Safdar et al. ${ }^{(10)}$ & 2004 & & & & $0.82(0.22-2.45)$ \\
\hline Silvestri et al..$^{(11)}$ & 2005 & & $0.89(0.16-4.95)$ & & \\
\hline Silvestri et al..$^{(12)}$ & 2007 & & $0.63(0.46-0.87)$ & & $0.74(0.61-0.91)$ \\
\hline Silvestri et al..$^{(13)}$ & 2008 & & & & \\
\hline Gram negative & & $0.07(0.04-0.13)$ & $0.36(0.22-0.60)$ & & \\
\hline Gram positive & & $0.52(0.34-0.78)$ & $1.03(0.75-1.41)$ & & \\
\hline Silvestri et al..$^{(14)}$ & 2009 & & & & $0.71(0.61-0.82)$ \\
\hline Liberati et al..$^{(15)}$ & 2009 & $0.28(0.20-0.38)$ & & & $0.75(0.65-0.87)$ \\
\hline Silvestri et al. ${ }^{(16)}$ & 2010 & & & $0.50(0.34-0.74)$ & $0.82(0.51-1.32)$ \\
\hline
\end{tabular}

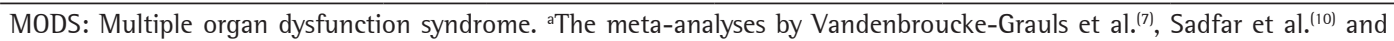
Silvestri et al. ${ }^{(16)}$ showed an impact on mortality. However, due to small sample size, the differences were not significant.

effective in preventing lower respiratory tract infection only in patients who receive mechanical ventilation for $48 \mathrm{~h}$ or less. The question of whether oral antiseptics are useful in preventing late-onset VAP requires further investigation. Furthermore, oral antiseptics have not been shown to significantly reduce mortality.

We believe SDD to be the only strategy that is associated with a survival benefit. We wonder why these authors chose to ignore this intervention in their review.

\section{Luciano Silvestri \\ Head of the Department of Anesthesia and Intensive Care, Presidio Ospedaliero, Gorizia, ltaly}

Hendrick K.F. van Saene Senior Lecturer, School of Clinical Sciences, University of Liverpool, Liverpool, UK

\author{
Liviano Folla \\ Head of Medicenter, \\ Center for Dentistry and Day Surgery, \\ Ronchi dei Legionari, Gorizia, Italy
}

\author{
Marco Milanese \\ Consultant, Department of Anesthesia \\ and Intensive Care, Presidio Ospedaliero, \\ Gorizia, Italy
}

\section{References}

1. Amaral SM, Cortês Ade Q, Pires FR. Nosocomial pneumonia: importance of the oral environment. J Bras Pneumol. 2009;35(11):1116-24.

2. Silvestri L, van Saene HK. Selective decontamination of the digestive tract does not increase resistance in critically ill patients: evidence from randomized controlled trials. Crit Care Med. 2006;34(7):2027-9; author reply 202930.

3. García-Hierro P, de la Cal MA, van Saene HK, Silvestri L [Article in Spanish]. A new clinical trial of selective digestive decontamination. Med Intensiva. 2009;33(6):297-300.

4. Silvestri L, van Saene HK, Zandstra DF, Viviani M, Gregori D. SDD, SOD or oropharyngeal chlorhexidine to prevent pneumonia and to reduce mortality in ventilated patients: which manoeuvre is evidence based? Intensive Care Med. In press 2010.

5. van Saene HK, Zandstra DF, Petros AJ, Silvestri L, De Gaudio AR. Infections in ICU: an ongoing challenge. In: Gullo A, Besso J, Lumb PD, Williams GF, editors. Intensive and critical care medicine. Milan: Springer Verlag; 2009. p. 261-72.

6. van Saene HK, Silvestri L, de la Cal MA, Baines P. The emperor's new clothes: the fairy tale continues. J Crit Care 2009;24(1):149-52.

7. Vandenbroucke-Grauls CM, Vandenbroucke JP. Effect of selective decontamination of the digestive tract on respiratory tract infections and mortality in the intensive care unit. Lancet. 1991;338(8771):859-62.

8. D’Amico R, Pifferi S, Leonetti C, Torri V, Tinazzi A, Liberati A. Effectiveness of antibiotic prophylaxis in critically ill adult patients: systematic review of randomised controlled trials. BMJ. 1998;316(7140):1275-85.

9. Liberati A, D’Amico R, Pifferi S, Torri V, Brazzi L, Parmelli E. Antibiotic prophylaxis to reduce respiratory tract infections and mortality in adults receiving intensive care. Cochrane Database Syst Rev 2004;(4):CD000022. 
10. Safdar N, Said A, Lucey MR. The role of selective digestive decontamination for reducing infection in patients undergoing liver transplantation: a systematic review and meta-analysis. Liver Transpl. 2004;10(7):817-27.

11. Silvestri L, van Saene HK, Milanese M, Gregori D. Impact of selective decontamination of the digestive tract on fungal carriage and infection: systematic review of randomized controlled trials.. Intensive Care Med. 2005;31(7):898-910.

12. Silvestri L, van Saene HK, Milanese M, Gregori D, Gullo A. Selective decontamination of the digestive tract reduces bacterial bloodstream infections and mortality in critically ill patients. Systematic review of randomised, controlled trials. J Hosp Infect. 2007;65(3):187-203.

13. Silvestri L, van Saene HK, Casarin A, Berlot G, Gullo A. Impact of selective decontamination of the digestive tract on carriage and infection due to Gram-negative and Gram-positive bacteria. A systematic review of randomised controlled trials. Anaesth Intensive Care. 2008;36(3):324-38.

14. Silvestri L, van Saene HK, Weir l, Gullo A. Survival benefit of the full selective digestive decontamination regimen. J Crit Care. 2009;24(3):474.e7-14.

15. Liberati A, D’Amico R, Pifferi S, Torri V, Brazzi L, Parmelli E. Antibiotic prophylaxis to reduce respiratory tract infections and mortality in adults receiving intensive care. Cochrane Database Syst Rev. 2009;(4):CD000022.

16. Silvestri L, van Saene HK, Zandstra DF, Marshall JC, Gregori D, Gullo A. Impact of selective decontamination of the digestive tract on multiple organ dysfunction syndrome: systematic review of randomized controlled trials. Crit Care Med. In press 2010. 